\title{
Pusat Bimbingan Karir (Career Centre) Sebagai Sarana Bimbingan Karir Bagi Mahasiswa Pendidikan Ekonomi Menuju Dunia Kerja
}

\section{Zetri Rahmat $^{1}$}

${ }^{1}$ Universitas Islam Negeri Sultan Syarif Kasim Riau

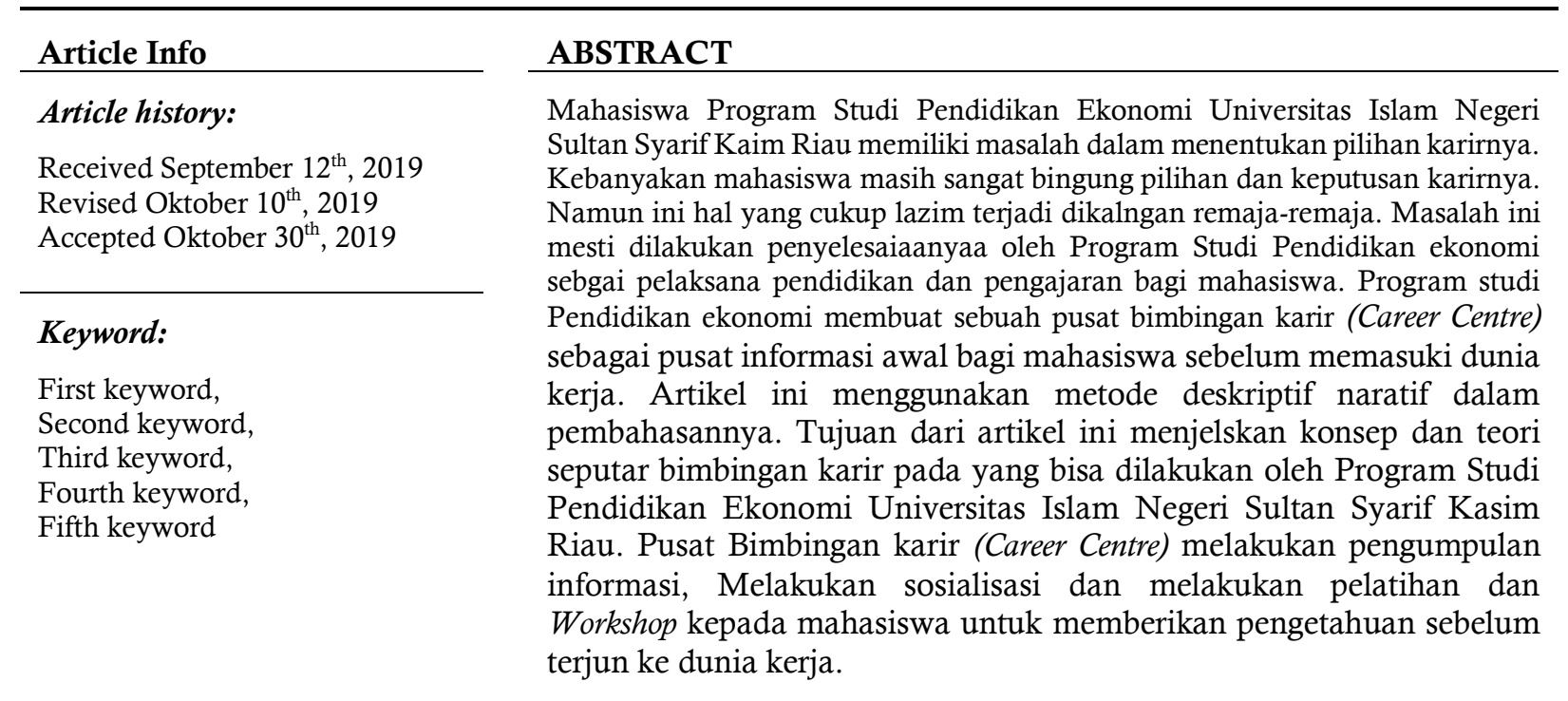

(C) 2019 The Authors. Published by UIN Sultan Syarif Kasim Riau. This is an open access article under the CC BY license (https://creativecommons.org/licenses/by/4.0)

\footnotetext{
Author:

Zetri Rahmat

Universitas Islam Negeri Sultan Syarif Kasim Riau

Email: zetri.rahmat@uin-suska.ac.id
}

\section{Pendahuluan}

Setiap Perguruan Tinggi berusaha menjadi lembaga yang berupaya membentuk mahasiswa menjadi mampu bersaing di dunia kerja melalui pembelajaran yang diterapkannya (Akmal, 2018). Kecepatan dan ketepatan lulusan dalam memperoleh pekerjaan juga sering disangkut-pautkan dengan kualitas sebuah Perguruan Tinggi, bahkan ini menjadi indikator penilaian, sebagai rujukan dalam penetapan akreditasi sebuah kampus. Mahasiswa merupakan output dari perguruan tinggi yang menjadi gambaran produk yang dihasilkan oleh sebuah perguruan tinggi. Ketika suatu perguruan tinggi menghasilkan mahasiswa yang baik, berarti perguruan tinggi itu berhasil melakukan tugasnya dengan baik. Maka seharusnya setiap perguruan tinggi harus memperhatikan mahasiswa yang diluluskanya. Salah satu fokus kualitas mahasiswa yang harus dipertimbangkan oleh perguruan tinggi adalah setiap lulusannya bisa diserap oleh dunia kerja.

Provinsi Riau merupakan salah satu provinsi yang ada di sumatera. Ibukota Provinsi Riau adalah Pekanbaru. Sama dengan kota lainnya Pekanbaru juga memiliki banyak pengangguran (GoRiau, 2019). Ini akan menjadi masalah 
yang besar jika dibiarkan. Makanya dengan hadirnya perguruan tinggi di provinsi ini maka diharapkan dapat mengurangi pengangguran yang ada di provinsi ini. Universitas Islam Negeri Sultan Syarif Kasim Riau merupakan satu-satunya Universitas negeri yang mengintegrasikan Islam dengan Pengetahuan, teknologi dan seni (UIN SUSKA Riau, 2019). Universitas Islam Negeri Sultan Syarif Kasim Riau memiliki puluhan Program Studi, salah satunya dalah Prgram Studi Pendidikan Ekonomi. Program studi Pendidikan Ekonomi adalah program studi yang cukup diminati oleh banyak mahasiswa. Program studi ini fokusnya menciptakan guru profesional, pekerja professional dan wirausaha yang memiliki karakter keislaman..

Setelah melakukan observasi awal yang dilakukan melalui survey online dengan menggunakan Googlefrom ditemukan bahwa banyak mahasiswa yang bingung dengan karir apa yang ingin dibangun setelah menempuh studi di Program studi Pendidikan ekonomi (Rahmat, 2019), keadaan ini tidak sesuai dengan visi program studi senidiri. Dari Survey yang dilakukan kebanyakan mahasiswa sudah memiliki rencana kerja namun kebanyakan pekerjaan tidak sesuai dengan jurusan yang mereka pilih. Pada umumnya ingin menjadi guru, pebisnis kuliner, dan pegawai negeri sipil. Hasil survei juga memperlihatkan bahwa mahasiswa sangat membutuhkan bimbingan karir pada Program Studi Pendidikan Ekonomi Universitas Islam Negeri Sultan Syarif Kasim Riau.

Kondisi mahasiswa yang bingung dalam menentukan karir sudah umum dikalangan remaja, kebanyak remaja masih ragu-ragu dan bingung dengan karir apa yang akan dia tempuh dimasa akan datang (Yulianto, 2012). Mahasiswa juga sering dibingungkan dalam pilihan-pilihan yang ada terkait karirnya (Hidayati, 2015). Remeja masa kini memiliki banyak keraguan dalam hidupnya khsusnya dibidang karir, mereka ragu dengan apa pekerjaan yang sesuai, kemampuan apa yang harus dimiliki, bagaimana harus berbaur atau menyesuaikan diri dengan individu, dan bagaimana berbaur dengan kelompok (Wibowo \& Tadjri, 2013). Keadaan seperti bingung dalam menentukan karir juga terjadi pada mahasiswa program studi pendidikan ekonomi berdasarkan survey yang dilakukan. Makanya perlu diambil kebijakan untuk membuat Career Centre (pusat bimbingan karir mahasiswa) agar setiap masalah yang ditemui oleh mahasiswa terkait dengan karirnya bisa diselesaikan dan didiskusikan bersama.

\section{Metode Penelitian}

Untuk membahas tentang pusat bimbingan karir (Career Centre) pada Program Studi Pendidikan Ekonomi, dalam hal ini menggunkan metode pembahasan berupa deskriptif naratif. Artikel ini bermaksud menjelaskan secara rinci tentang konsep dan keadaan sesungguhnya tentang bimbingan karir (Career Centre) pada Program Studi Pendidikan Ekonomi.

\section{Pembahasan}

Bimbingan dan konseling adalah sesuatu yang penting bagi peserta didik, karena bimbingan dan konseling berusaha memberikan bantuan kepada peserta didik dalam upaya menggenali pribadinya, mengenali lingkungannya dan merencanakan masa depannya (Hadi, Yusuf, \& Syahniar, 2013). Bimbingan karir merupakan bagian dari bimbingan dan konseling. Bimbingan karir ini sangat penting bagi setiap peserta didik. Memenuhi kebutuhan perkembangan peserta didik untuk menyesuaikan diri dan mengintegrasikan antara bidang stsudi pelajaran dengan dunia kerja merupakan salah satu sarana layanan yang diberikan oleh bimbingan karir (Wibowo \& Tadjri, 2013). Bimbingan karir dilakukan sebagai upaya mempersiapkan diri peserta didik untuk siap menghadapi dunia kerja, memilih pekerjan yang tepat. Pada bimbingan karir di lingkungan pergguruan tinggi, bimbingan karir dilakukan agar para mahasiswa mampu profesional dalam pekerjaan dan mampu memenuhi tantangan pada profesinya masingmasing.

Bimbingan karir dilakukan oleh konselor pada berbagai lingkungan. Tujuannya untuk memfasilitasi seseorang agar melakukan perkembangan pada karirnya disepanjang usia kerjanya (Hidayati, 2015). Bimbingan karir pada sebuah perguruan tinggi tidak hanya menyediakan program untuk membuat mahasiswa masuk ke dalam dunia kerja, namun juga meningkatkan kualitsa mahasiswa sehingga memiliki standar yang sangat tinggi (Melrose \& Reid, 2001). Bimbingan karir pada sebuah perguruan tinggi seharusnya mempunya tgas atau peran yang cukup luas karena tidak hanya sekedar memikirkan dimana lulusan akan bekerja namunya juuga memperhatikan personal dari lulusan yang dihasilkan. Pembentukan karakter dari mahasiswa juga menjadi pekerjaan yang harus dilakukan bimbingan karir pada sebuah perguruan tinggi.

Bimbingan Karir (Career Centre) pada sebuah perguruan tinggi sangat banyak manfaatnya. Dengan adanya bimbingan karir ini bisa menjadi pusat informasi menuju dunia kerja, merancang karir dan meyelesaikan masalah terkait karirnya (Subhan, Hasgimianti, Sari, Bakar, \& Amat, 2019). Bimbingan karir bisa memberikan sosialisasi kepada mahasiswa untuk meyampaikan pekerjaan yang seperti apa sedang banyak dibutuhkan. Selanjutnya bimbingan karir juga bisa memberikan gambaran karakter pekerja yang seperti apa yang sedang dibutuhkan oleh pasar tenaga kerja 


\section{Proses Bimbingan Karir}

Ada banyak tahapan yang ditempuh dalam melakukan bimbingan Karir yaitu perencanaan, pengambilan keputusan, penyesuai diri (Hidayati, 2015). Pada tahap perencanaan konselor melakukan pengamatan awal terkait minat dan bakat peserta didik. Selanjutnya disesuaikan dengan jenis-jenis perkejaan yang tersedia. Link and match antara pekerjaan dengan minat dan bakat peserta didik ini memegang pengaruh yang sangat besar karena ini terkait kemampuan dasar masing-masing individu dalam bekerja. Ketika sesorang tidak memiliki minat dalam sebuah pekerjaan maka tidak akan mampu melakukan pekerjaan itu degan baik.

Proses perencanaa bisa dilakukan memeriksa data diri terkait dengan peserta didik, selanjutnya melakukan kegiatan wawancara. Wawancara dengan menanyakan hal-hal yang bisa memetakan minat dan bakat dari peserta didik. Seorang konselor harus memiliki kemampuan komunikasi yang baik, terampil dan sensitif. Agar setiap peserta didik bisa mengungkapkan dengan jelas terkait identitas diri peserta didik yang melakukan bimbingan karir.

Tahap kedua adalah pegambilan keputusan. Pengambilan keputusan dilakukan dengan kegiatan disukusi antara konselor dengan peserta didik. Konselor memberikan pengarahan-pengarahan terkait karir yang tersedia di dunia kerja. Selanjutnya peserta didik bisa menanyakan hal yang ingin ditanyakan. Ini yang menjadi dasar-dasar pertibangan dalam pengambilan keputusan.

Dalam Bimbingan dan Konseling proses pengambilan keputusan dilakukan oleh peserta didik sendiri karena konselor hanya mengarahkan. Setiap orang dianggap pakar dalam pengambilan keputusan untuk dirinya sendiri. Peran konselor hanya membantu memberikan arahan dan pandangan terkait masalah karir yang dihadapi oleh peserta didik.

Tahap terakhir adalah penyesuaian diri. Setelah melakukan perencanaan dan pengambilan keputusan, peserta didik melakukan penyesuain diri dengan pilihan karir yang diinginkan dengan bantuan bimbingan dari konselor. Konselor memberikan kriteria khusus kepada peserta didik. Kriteria ini harus dimiliki peserta didik agar mudah diterima pada posisi yang diinginkan. Setiap peserta didik harus memenuhi kriteria tersebut agar bisa menyesuaikan dengan pekerjaan yang nantinya akan dilakukan oleh peserta didik.

\section{Proses Bimbingan Karir Mahasiswa Pendidikan Ekonomi}

Program Studi Pendidikan Ekonomi Universitas Islam Negeri Sultan Syarif Kasim Riau selaku penyelenggara kegiatan belajar dan mengajar kepada mahasiswa, sebaiknya membuat sebuah pusat bimbingan karir (Career Centre) untuk mahasiswa. Bimbingan karir ini dijadikan sebagai media konsultasi bagi mahasiswa pendidikan ekonomi untuk mendapatkan informasi peluang kerja yang tersedia dan sedang dibutuhkan. Agar saat mahasiswa menyelsaikan pendidikannya, mereka bisa memahami pilihan-pilihan pekerjaan yang tersedia dan bisa dimasuikinya dengan waktu tunggu yang tidak terlalu lama.

Pendidikan Ekonomi Universitas Islam Negeri Sultan Syarif Kasim Riau memiliki tujuan agar mampu menghasilkan lulusan yang profesional di bidang Pendidikan dan Kewirausahaan. Hal ini harus ditindak lanjuti atau direspon dengan melakukan kerja sama dengan sekolah-sekolah dan lembaga-lembaga pendidikan lainnya, agar mampu melakukan pemetaan peluang kerjaa apa saja yang sedang banyak dibutuhkandi dunia kerja. Pengumpulan informasi juga harus selalu dilakukan agar selalu mengetahui berita terbaru tentang perkembangan pendidikan. Informasi ini yang nantinya dijadikan sebgai dasar apa saja kriteria yang harus dimiliki oleh lulusan untuk bisa di serap oleh dunia kerja khususnya pada bidang pendidikan.

Kegiatan sosialisai harus juga rutin dilakukan kepada mahasiswa. Tujuannya supaya setiap mahasiswa memiliki pengetahuan dan informasi tentang dunia kerja yang akan mereka hadapi kedepannya. Pusat bimbingan karir juga harus banyak bertanya kepada pimpinan-pimpinan sekolah atau lembaga pendidikan lain, terkait dengan apa saja kriteria guru yang sangat dibutuhkan saat ini. Hasil ini bisa memberikan pertimbangan untuk membuat kebijakan bagi Program Studi Pendidikan Ekonomi Universitas Islam Negeri Sultan Syarif Kasim Riau terkait mata kuliah diajarkan dan apa saja kegiatan kampus yang bisa menujung kemampuan mahasiswa. Sehingga mahasiswa yang dihasilkan benar-benar matang dan siap menghadapi dunia kerja.

Pusat bimbingan karir (career centre) juga harus melakukan pelatihan dan workshop. Kegiatan ini dilakukan untuk menambah skill dan kompetensi mahasiswa. Kegiatan pelatihan ini mestinya diberikan langsung oleh orang yang benar-benar pakar dibidang pendidikan dan merupakan praktsi pendidikan. Sehingga materi yang diberikan tidak hanya teori-teori saja yang membuat mahasiswa menjadi bingung dalam meaksanakannya dilapangan. Ketika mahasiswa menerima informasi langsung dari pelaku atau praktisi pendidikan ini akan membuat informasi yang diserap lebih aktual dan bisa diaplikasikan oleh mahasiswa.

Pengumpulan informasi, kegiatan sosialisasi dan melakukan pelatihan dan workshop akan memberikan dampak yang baik bagi mahasiswa. Paling tidak mahasiswa sudah memiliki pengetahuan dasar dalam persipan menuju dunia kerja. Nantinya saat lulus mereka siap menghadapi dunia kerja. Dan bisa bersaing di dunia kerja yang semakin lama akan sekamin ketat persaingannya. 


\section{Manfaat Bimbingan Karir}

Pusat bimbingan karir (Career Centre) bagi mahasiswa memberikan banyak manfaat, seperti:

1. Mahasiswa memliliki engetahuan seputar karir yang akan dipilihnya dimasa mendatang.

2. Mahasiswa bisa mengetahui apa saja kriteria pekerjaan yang diinginkan dan menyesuaikan dengan kemampuan dirinya.

3. Mahasiswa bisa berdiskusi terkait karir yang cocok dengan dirinya sehingga tidak bingung lagi dengan karirnya dimasa mendatang.

4. Memberikan kompetensi dan skill khusus kepada mahasiswa saat ketika diadakan kegiatan pelatihan dan workshop.

5. Mahasiswa bisa mengetahui informasi lowongan kerja yang didapatkan oleh pusat bimbingan karir (career centre).

6. Perguruan tinggi akan mampu meningkatkan kualitas mahasiswanya ketika sering berkomunikasi dengan pihak sekolah atau lembaga pendidikan selaku penyerap lapangan kerja.

7. Perguruan tinggi akan mampu meningkatkan akreditasinya ketika Pusat Bimbingan karir bekerja dengan baik dan mampu mengantarkan mahasiswa lulusan bekerja dalam waktu tunggu yang sangat singkat.

8. Mengurangi penangguran yang ada pada sebuah negera.

\section{Kesimpulan}

Pusat bimbingan karir (career centre) merupakan sarana bagi mahasiswa untuk bertanya, berdiskusi dan menyelesaikan masalah terkait karir mahasiswa. Dengan adanya bimbingan karir (career centre) bisa memberikan pengetahuan awal tentang karir yang akan dihadapi oleh mahasiswa. Program Studi Pendidikan Ekonomi Universitas Islam Negeri Sultan Syarif Kasim Riau sebaiknya merencakan pembuatan Pusat bimbingan karir (career centre) karena mampu memberukan banyak manfaat. Pusat bimbingan karir (career centre) memberikan manfaat pada banyak pihak yaitu: Mahasiswa, Perguruan Tinggi dan Negara.

\section{Daftar Rujukan}

Akmal, A. (2018). PERANAN PEMBELAJARAN KEWIRAUSAHAAN DALAM MEMBENTUK KARAKTER YANG ISLAMI PADA MAHASISWA PENDIDIKAN EKONOMI UIN SUSKA RIAU. Eklektik: Jurnal Pendidikan Ekonomi Dan Kewirausahaan, 1(1), 32-52.

GoRiau. (2019). GoRiau - 190.140 Orang di Riau Masih Jadi Pengangguran. Retrieved January 6, 2019, from GoRiau website: https://www.goriau.com/berita/baca/190140-orang-di-riau-masih-jadipengangguran.html

Hadi, M. F. Z., Yusuf, A. M., \& Syahniar, S. (2013). Pemahaman Konselor Sekolah tentang Tugas Perkembangan Siswa dan Layanan yang Diberikan. Konselor, 2(1).

Hidayati, R. (2015). Layanan Informasi karir membantu peserta didik dalam meningkatkan pemahaman karir. Jurnal Konseling GUSJIGANG, 1(1).

Melrose, M. J., \& Reid, M. D. (2001). A quality career centre. Quality in Higher Education, 7(3), 207-216.

Rahmat, Z. (2019). Observasi Awal Perencanaa karir (Responses) - Google Sheets. Retrieved January 6, 2019, from

https://docs.google.com/spreadsheets/d/1sokMbC8U5gn1dOo61RDCGC1oU0j3Kd3L8eGHByYZae 8/edit\#gid=1638677904

Subhan, M., Hasgimianti, H., Sari, W. P., Bakar, A. Y. A., \& Amat, S. (2019). Kematangan Karir Mahasiswa Prodi Ekonomi Dalam Pemilihan Karir. Educational Guidance and Counseling Development Journal, 2(2), $50-54$.

UIN SUSKA Riau. (2019). Visi, Karateristik, Misi dan Tujuan - Universitas Islam Negeri Sultan Syarif Kasim Riau. Retrieved January 7, 2019, from https://uin-suska.ac.id/profil/visi-dan-misi/

Wibowo, D. M. L. M. E., \& Tadjri, I. (2013). Pengembangan modul bimbingan karir berbasis multimedia 
interaktif untuk meningkatkan kematangan karir siswa. Jumal Bimbingan Konseling, 2(1).

Yulianto, U. (2012). Pengaruh konseling karir secara kelompok terhadap efikasi diri pengambilan keputusan studi lanjut pada siswa SMA. Universitas Gadjah Mada. 